University of Nebraska - Lincoln

DigitalCommons@University of Nebraska - Lincoln

\title{
SPONGIFORM ENCEPHALOPATHY IN FREE-RANGING MULE DEER (ODOCOILEUS HEMIONUS), WHITE-TAILED DEER (ODOCOILEUS VIRGINIANUS) AND ROCKY MOUNTAIN ELK (CERVUS ELAPHUS NELSONI) IN NORTHCENTRAL COLORADO
}

T. R. Spraker

Colorado State University - Fort Collins

M. W. Miller

Colorado Division of Wildlife

E. S. Williams

University of Wyoming

D. M. Getzy

Colorado State University - Fort Collins

W. J. Adrian

Colorado Division of Wildlife

Follow this and additional works at: https://digitalcommons.unl.edu/zoonoticspub

Spraker, T. R.; Miller, M. W.; Williams, E. S.; Getzy, D. M.; Adrian, W. J.; Schoonveid, G. G.; Spowart, R. A.; O'Rourke, Katherine I.; Miller, J. M.; and Merz, P. A., "SPONGIFORM ENCEPHALOPATHY IN FREE-RANGING MULE DEER (ODOCOILEUS HEMIONUS), WHITE-TAILED DEER (ODOCOILEUS VIRGINIANUS) AND ROCKY MOUNTAIN ELK (CERVUS ELAPHUS NELSONI) IN NORTHCENTRAL COLORADO" (1997). Other Publications in Zoonotics and Wildlife Disease. 147.

https://digitalcommons.unl.edu/zoonoticspub/147

This Article is brought to you for free and open access by the Wildlife Disease and Zoonotics at DigitalCommons@University of Nebraska - Lincoln. It has been accepted for inclusion in Other Publications in Zoonotics and Wildlife Disease by an authorized administrator of DigitalCommons@University of Nebraska Lincoln. 


\section{Authors}

T. R. Spraker, M. W. Miller, E. S. Williams, D. M. Getzy, W. J. Adrian, G. G. Schoonveid, R. A. Spowart, Katherine I. O'Rourke, J. M. Miller, and P. A. Merz 


\title{
SPONGIFORM ENCEPHALOPATHY IN FREE-RANGING MULE DEER (ODOCOILEUS HEMIONUS), WHITE-TAILED DEER (ODOCOILEUS VIRGINIANUS) AND ROCKY MOUNTAIN ELK (CERVUS ELAPHUS NELSONI) IN NORTHCENTRAL COLORADO
}

\author{
T. R. Spraker,' M. W. Miller, ${ }^{2}$ E. S. Williams, ${ }^{3}$ D. M. Getzy, ${ }^{1}$ W. J. Adrian, ${ }^{2}$ G. G. Schoonveld, ${ }^{2}$ \\ R. A. Spowart, ${ }^{2}$ K. I. O'Rourke, ${ }^{4}$ J. M. Miller, ${ }^{5}$ and P. A. Merz ${ }^{6}$ \\ ' Colorado State Diagnostic Laboratory, College of Veterinary Medicine, Colorado State University, Fort Collins, \\ Colorado 80523, USA \\ 2 Colorado Division of Wildlife, 317 West Prospect Road, Fort Collins, Colorado 80526, USA \\ ${ }^{3}$ Department of Veterinary Sciences, University of Wyoming, 1174 Snowy Range Road, University of Wyoming, \\ Laramie, Wyoming 82070, USA \\ 4 USDA-ARS, 337 Bustad, Washington State University, Pullman, Washington 99164, USA \\ 5 USDA-ARS, National Animal Disease Center, Box 70, Ames, lowa 50010, USA \\ - New York State Institute for Basic Research, 1050 Forest Hill Road, Staten Island, New York 10314, USA
}

ABSTRAC: Between March 1981 and June 1995, a neurological disease characterized histologically by spongiform encephalopathy was diagnosed in 49 free-ranging cervids from northcentral Colorado (USA). Mule deer (Odocoileus hemionus) were the primary species affected and accounted for 41 (84\%) of the 49 cases, but six Rocky Mountain elk (Cervus elaphus nelsoni) and two white-tailed deer (Odocoileus virginianus) were also affected. Clinical signs included emaciation, excessive salivation, behavioral changes, ataxia, and weakness. Emaciation with total loss of subcutaneous and abdominal adipose tissue and serous atrophy of remaining fat depots were the only consistent gross findings. Spongiform encephalopathy characterized by microcavitation of gray matter, intraneuronal vacuolation and neuronal degeneration was observed microscopically in all cases. Scrapie-associated prion protein or an antigenically indistinguishable protein was demonstrated in brains from 26 affected animals, 10 using an immunohistochemical staining procedure, nine using electron microscopy, and seven using Western blot. Clinical signs, gross and microscopic lesions and ancillary test findings in affected deer and elk were indistinguishable from those reported in chronic wasting disease of captive cervids. Prevalence estimates, transmissibility, host range, distribution, origins, and management implications of spongiform encephalopathy in free-ranging deer and elk remain undetermined.

Key words: Spongiform encephalopathy, chronic wasting disease, mule deer, white-tailed deer, Rocky Mountain elk, Odocoileus hemionus, Odocoileus virginianus, Cervus elaphus nelsoni.

\section{INTRODUCTION}

Chronic wasting disease (CWD), characterized by progressive loss of body condition and abnormal behavior, was first recognized in 1967 by biologists working with captive mule deer (Odocoileus hemionus) and mule deer $\times$ white-tailed deer (Odocoileus virginianus) hybrids held at wildlife research facilities in Fort Collins, Colorado, USA (Williams and Young, 1980). A similar syndrome was subsequently recognized in captive deer at a research facility near Wheatland, Wyoming (USA) in 1978 (Williams and Young, 1980) and in captive Rocky Mountain elk (Cervus elaphus nelsoni) at both the Colorado and Wyoming facilities (Williams and
Young, 1982). Based on clinical features, postmortem examinations, and histopathologic lesions, CWD of mule deer and elk was classified as a transmissible spongiform encephalopathy (Williams and Young, 1992). Chronic wasting disease of captive deer and elk shares many epizootiologic, clinical, and pathologic features with scrapie of sheep and goats, bovine spongiform encephalopathy, and spongiform encephalopathies of other mammalian species (Williams and Young, 1992).

Here, we report clinical, pathological, and epizootiological observations on 49 cases of naturally-occurring spongiform encephalopathy in free-ranging cervids including mule deer, white-tailed deer and elk. 


\section{MATERIALS AND METHODS}

All cases originated from northcentral Colorado $\left(40^{\circ} 15^{\prime}\right.$ to $40^{\circ} 55^{\prime} \mathrm{N}, 103^{\circ} 50^{\prime}$ to $\left.105^{\circ} 45^{\prime} \mathrm{W}\right)$ between March 1981 and June 1995. Affected deer and elk were usually observed by local residents who reported sick or dead animals to personnel of either the Colorado Division of Wildlife (CDOW; Fort Collins, Colorado) or the Colorado State Diagnostic Laboratory (CSDL; Fort Collins).

Affected animals were either found dead, euthanized in the field by gunshot, or captured alive and euthanized via gunshot, lethal injection, or electrocution under deep anesthesia. For cases where complete records were available, pentobarbital sodium solution (Beuthanasia-D Special; Schering-Plough Animal Health Corporation, Kenilworth, New Jersey, USA) or a combination of embutramide, mebezonium iodide, and tetracaine hydrochloride (HCl) (T-61 ${ }^{\circledR}$; Hoechst-Roussel Agri-Vet Company, Somerville, New Jersey) was used for lethal injections; xylazine $\mathrm{HCl}$ (multiple sources), alone or in combination with ketamine $\mathrm{HCl}$ (multiple sources), was used to induce deep anesthesia prior to electrocution. Two bucks were shot by hunters during regular hunting seasons and presented to wildlife officers.

Ages were estimated by examining dental eruption and wear patterns (Quimby and Gaab, 1957; Robinette et al., 1957) or counting cementum annuli (Erickson and Seliger, 1969; Keiss, 1969). When possible, complete necropsies were performed on affected animals and representative tissues from all major organ systems were collected and fixed in $10 \%$ neutral buffered formalin. Tissues were embedded in paraffin, sectioned at 5 to $6 \mu \mathrm{m}$ and stained with hematoxylin and eosin $(\mathrm{H} \& \mathrm{E})$. Selected tissues of the central nervous system were stained with luxol fast blue-cresyl echt violet, Bodian's silver, periodic acid-Schiff (PAS) and Congo red (Luna, 1992); in two cases we searched for PAS-positive and birefringent amyloid plaques. Formalin-fixed brain tissues from 10 affected and seven unaffected mule deer were also immunostained for scrapie-associated prion protein ( $\mathrm{PrPS}^{\mathrm{S}}$ ) or antigenically similar protein (Miller et al., 1994).

Fresh brain tissues from seven mule deer with and four without histological lesions of spongiform encephalopathy were analyzed by Western blot to detect PrPSc or antigenically similar protein (O'Rourke et al., 1994); this assay was used to detect proteinase- $K$ resistant prion protein (PrP) using antiserum directed against hamster prion peptide GQGGGTHNQWNKPSK in banding between 27 and 30 kilodaltons (kd). Fresh brain tissues from eight mule deer, two elk

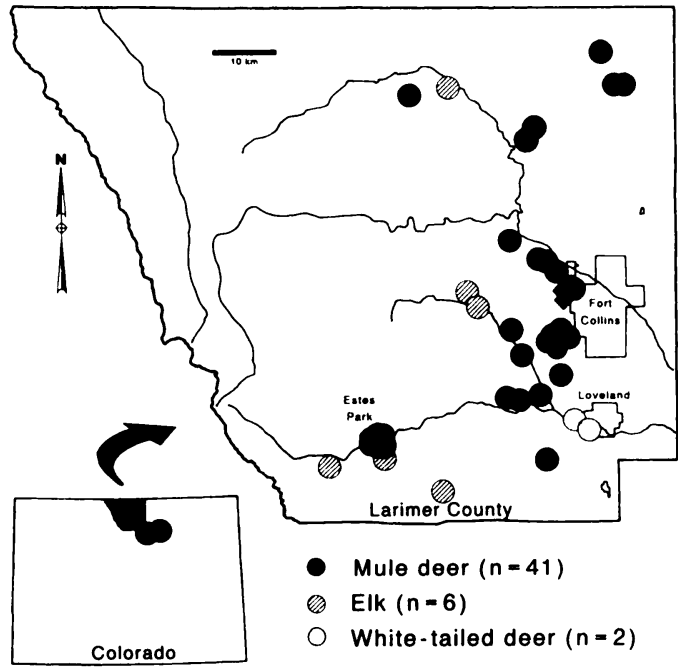

Figure 1. Distribution of 49 cases of spongiform encephalopathy in free-ranging deer and elk from northcentral Colorado submitted between March 1981 and June 1995. All but two cases (inset) occurred in Larimer County. Dots are approximate sites where animals died or were collected; black diamonds west of Fort Collins are locations of two wildlife research facilities where chronic wasting disease was described previously.

and one white-tailed deer with histological lesions of spongiform encephalopathy and 11 mule deer without lesions were also examined via electron microscopy for presence of scrapie-associated fibrils (SAFs) (Merz et al., 1981).

\section{RESULTS}

All 49 free-ranging cervids with histological lesions of spongiform encephalopathy were found within a $100 \mathrm{~km}$ radius of Fort Collins, Colorado (Fig. 1). These cervids included 41 mule deer (25 males, 16 females), two male white-tailed deer, and six elk (five females, one male). Estimated ages ranged from 2.5 to $7.5 \mathrm{yr}$ for deer and from 1.8 to $10.5 \mathrm{yr}$ for elk. Forty-two (86\%) of the 49 cases were submitted between the months of October and April. Clinical signs included loss of fear of humans, ataxia, marked weakness, inability to stand, dehydration, rough dull haircoat, excessive salivation, drooping of the head and ears, and severe emaciation. None of the animals had any distinguishing features 
such as ear tags, and therefore we believe all affected individuals were free-ranging.

The primary gross lesions were emaciation accompanied by generalized absence or serous atrophy of subcutaneous and visceral adipose tissue and yellow gelatinous bone marrow. Subacute to chronic bronchopneumonia was found in 11 animals (eight mule deer, one white-tailed deer and two elk). Abomasal or omasal ulcers were found in seven mule deer. Marked enlargement of the adrenal glands was observed in 16 mule deer. Two mule deer had oral foreign bodies. Rumen contents in 10 mule deer were watery or frothy, and rumens from affected animals often contained sand. Three of 16 female mule deer were pregnant; one had a single fetus and two had three fetuses. All affected animals were otherwise of normal stature for their age.

We found histological lesions in a variety of organ systems; however, the predominant and most consistent lesions were in the brain and spinal cord. Spongiform encephalopathy characterized by microcavitation primarily of the gray matter with single or multiple intracytoplasmic vacuoles in neuronal perikarya and neuronal degeneration was found in neural tissues (Fig. 2). Areas most severely affected within the telencephalon included olfactory bulbs, olfactory stria, and septal nuclei. Structures of diencephalon most severely affected included thalamic nucleus, supraoptic nucleus, and paraventricular nucleus. Areas of the mesencephalon most severely affected included the central gray substance and the tegmental nuclei. Areas of medulla oblongata consistently and most severely affected included neurons of reticular formation, hypoglossal nucleus, parasympathetic nucleus of the vagus nerve, medial and lateral cuneatus nuclei, and nucleus of the spinal tract of the trigeminal nerve. Nuclei occasionally affected included oculomotor nucleus, interpeduncular nucleus, red nucleus, habenular nucleus, and pons. Neurons of cerebral cortex and cerebellum, including Purkinje

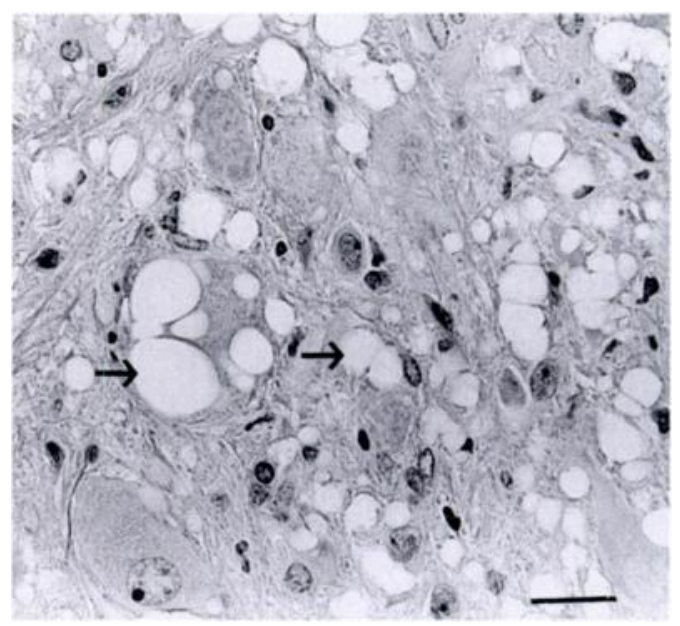

Ficiure 2. Parasympathetic nucleus of the vagus nerve in the medulla oblongata of a mule deer affected with spongiform encephalopathy: Note the vacuolation within neuronal perikarya and neuropil (arrows) $(\mathrm{H} \& \mathrm{E})$. Bar $=300 \mu \mathrm{m}$.

cells, were occasionally affected. Occasional small areas of microcavitation could be found in the molecular layer of the cerebellum. Neurons of the gray matter of the spinal cord were occasionally affected. Astrocytic hypertrophy and hyperplasia with fibrillary proliferation were found within areas of spongiform change. Both cases examined for amyloid plaques were positive.

Protein antigenically indistinguishable from $\mathrm{PrPSc}^{\mathrm{Sc}}$ was demonstrated with immunohistochemical stains in brain tissues from all 10 spongiform encephalopathy cases examined (Fig. 3), but not in brain tissues of seven deer that did not have spongiform encephalopathy. Similarly, with Western blots we detected $\mathrm{PrP}$ in all seven mule deer with histological lesions of spongiform encephalopathy, but in none of four samples from unaffected deer. Using electron microscopy, we observed SAFs in brain tissue from cervids with histological lesions of spongiform encephalopathy; fibrils were not found in brain tissue from mule deer without such lesions.

\section{DISCUSSION}

The clinical signs and neurohistological lesions found in these 49 free-ranging cer- 


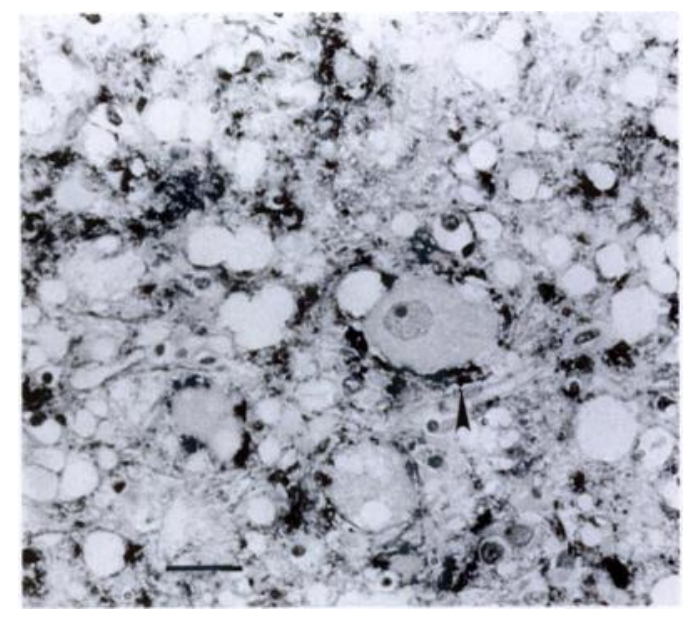

FIc:URE 3. Positive immunohistochemical staining of scrapie-associated prion protein in a section from the vagal parasympathetic nucleus of a mule deer affected with spongiform encephalopathy. Note the dark-staining droplets aromnd a large neuron (arrow). Bar $=300 \mu \mathrm{m}$.

vids were indistinguishable from those described in CWD of captive mule deer and Rocky Mountain elk (Williams and Young, 1992, 1993). Positive immunostaining with anti-PrP serum and SAFs occurred in brain tissues from both free-ranging spongiform encephalopathy cases, as reported here, and from CWD cases in captive cervids (Guiroy et al., 1991a, b). In light of these similarities, we believe the cases described here represent naturally occurring spongiform encephalopathy caused by an agent that is likely identical to the etiologic agent or agents of CWD in captive cervids and similar to the etiologic agent or agents of scrapie and other transmissible spongiform encephalopathies.

The source of spongiform encephalopathy in free-ranging cervids is undetermined. It may represent spill-over of scrapie from domestic sheep. However, spongiform encephalopathy has not been reported in captive or wild cervids from parts of North America and the United Kingdom where scrapie is far more prevalent than in northcentral Colorado. Alternatively, this disease may represent a spontaneous, naturally occurring spongiform encephalopathy of cervids that simply has not been detected elsewhere. The source or origin of spongiform encephalopathy in wild cervids, as in captive cervids, will be virtually impossible to determine retrospectively. Similarly, explanation of the geographic localization of free-ranging and captive cases remains equivocal.

The mode of transmission of spongiform encephalopathy in free-ranging cervids also is unknown. Both circumstantial and experimental data implicate animal-to-animal transmission of CWD in captive cervids (Williams and Young, 1992; E. S. Williams, M. W. Miller, unpubl.). Similarly, horizontal transmission of scrapie has been documented in sheep (Greig, 1940; Dickinson et al., 1974; Hourrigan et al., 1979), from sheep to goats (Stamp, 1962; Hourrigan et al., 1969; Stemshorn, 1975), and among goats (Hourrigan et al., 1979). Although specific transmission mechanisms are equally cryptic, it is possible that feeding of deer and elk by local residents in Estes Park and other developments may be a contributing factor. If this disease is transmitted horizontally, either by direct contact or environmental contamination, then artificial feeding stations for wild cervids could be exacerbating the problem on a local level.

Equally little is known about other aspects of the epizootiology of spongiform encephalopathy in wild cervids. The number of case submissions has increased from $<1 /$ year to $>1 /$ month since the first case was diagnosed in 1981. We believe this increased detection rate is mostly due to greater efforts to locate affected animals, but recognize it also could reflect an increased occurrence and spread of the disease. Encroachment of human development into native habitats in Larimer County has resulted in more deer and elk living near rural and suburban homes over the last $15 \mathrm{yr}$. Wild cervid herds in this area are most visible and in closest proximity to human population centers during winter, and this may partially explain why most cases have been submitted between October and April. It follows that greater 
opportunity for human and cervid interactions could have enhanced the chances of sick animals being observed and reported in recent years. Although the occurrence of spongiform encephalopathy in wild cervids could be on the rise in this area, preliminary analyses of deer and elk harvest survey data from 1990 to 1994 do not reflect such a trend (Miller et al., 1995; M. W. Miller, unpubl.).

Most free-ranging cervids dying from spongiform encephalopathy were between 2.5 and $7 \mathrm{yr}$ old at post mortem. This is the same age group that succumbs to CWD of captive mule deer and elk (Williams and Young, 1980, 1982). Despite severe emaciation, wild cervids examined here were of normal body stature and males had normal antler development for their age and the season. Clinical disease in a 21-mo-old elk demonstrates incubation can be $<2 \mathrm{yr}$ in free-ranging individuals. The wide range of ages observed in affected cervids could be a result of variable incubation period, varied ages at initial infection, or a combination of these factors.

The importance of spongiform encephalopathy in wild deer and elk is unclear. Because so little is known about the etiology and epizootiology of spongiform encephalopathy in wild cervids, strategies for managing this disease in free-ranging populations have not been identified. Although minimizing the occurrence and distribution of spongiform encephalopathy in wild cervids is a desirable goal, additional research on the many poorly understood aspects of this disease will be necessary before effective management programs can be developed and implemented by responsible state wildlife management agencies.

\section{ACKNOWLEDGMENTS}

This work was supported by Federal Aid in Wildlife Restoration Project W-153-R. We thank B. Olmstead, S. Steinert, H. Spear, D. Clarkson, P. Dorsey, C. Crawford, J. Jackson, M. Leslie, and L. Evans for assistance with case submissions; C. Hearn and V. Welch for tech- nical assistance; and L. Mickelsen for technical assistance with Western blot immunoassays. D. Baker, T. Beck, W. Snyder, M. Wild, two anonymous reviewers, and an assistant editor provided valuable reviews of earlier drafts of this manuscript.

\section{LITERATURE CITED}

Dickinson, A. G., J. T. Stamp, and C. C. ReNwick. 1974. Maternal and lateral transmission of scrapie in sheep. Journal of Comparative Pathology 84: $19-25$.

ERICKSON, J. A., AND W. G. SElicier. 1969. Efficient sectioning of incisors for estimating ages of mule deer. The Journal of Wildlife Management 3.3: 384-388.

Greic, J. R. 1940. Scrapie: Obsenations on the transmission of the disease of mediate contact. Veterinany Journal 96: 203-206.

(GUIROY, D. C., E. S. Williams, R. YaNaGiHaRA, ANi) D. C. GajDuSEK. 1991a. Topographic distribution of scrapie amyloid-immunoreactive plaques in chronic wasting disease in captive mule deer (Odocoileus hemionus). Acta Neuropathologica 81: $475-478$.

$\longrightarrow,-, \longrightarrow$ AND $\longrightarrow$ 1991b. Immunolocalization of scrapie amyloid (PrP27-30) in chronic wasting disease of Rocky Mountain elk and hybrids of captive mule deer and whitetailed deer. Neuroscience Letters 126: 195-198.

Hourrigan, J. L., A. L. Klingspori, H. A. MCDANIEl, AND M. N. RIEMENSChNeIDER. 1969. Natural scrapie in a goat. Journal of the American Veterinary Medical Association 154: 5.385.39 .

- W. W. CLARK, AND M. DE CAMP 1979. Epidemiology of scrapie in the United States. In Slow transmissible diseases of the nervous system, Vol. I, S. B. Prusiner and W. J. I Iadlow (editors). Academic Press, London, England. pp. 331-356.

KEISS, R. E. 1969. Comparison of eruption-wear patterns and cementum anmuli as age criteria in elk. The Journal of Wildlife Management 33: 175-180.

LUNA, L. G. 1992. Histopathologic methods and color atlas of special stains and tissue artifacts. Johnson Printers, Downers Grove, Illinois, $767 \mathrm{pp}$.

MERz, P. A., R. A. SOMERTille, H. M. IVISNiEWSKi AND K. IQBAL. 1981. Abnormal fibrils from scrapie-infected brain. Acta Neuropathologica 54: 63-74.

MILlek, J. M., A. L. JeNiY, W. D. TayloR, R. E. RACE, D. R. ERNST, J. B. KATZ, AND R. RuBENSTEIN. 1994. Detection of prion protein in formalin-fixed brain by hydrated autoclating immunohistochemistry for the diagnosis of scrapie in sheep. Journal of Veterinary. Diagnostic Investigations 6: $366-368$. 
Miller, M. W., C. W. MCCaRTy, C. A. Mehaffy, R. FORD, AND E. S. Williams. 1995. Monitoring and managing wildlife health in Colorado. In Wildlife research report, mammals research, Federal Aid Projects, Job Progress Report, Project W-153-R-8, Work Plan la, Job 6. Colorado Division of Wildlife, Fort Collins, Colorado, pp. 141-150.

O'Rourke, K. I., T. P. HufF, C. W. Leathers, M. M. Robinson, and J. R. Gorham. 1994. SCID mouse spleen does not support scrapie replication. Journal of General Virology 75: 1511-1514.

QuimbY, D. C., AND J. E. GaAB. 1957. Mandibular dentition as an age indicator in Rocky Mountain elk. The Journal of Wildlife Management 21: 435-451.

Robinette, W. L., D. A. Jones, G. Rogers, AND GASHWILER. 1957. Notes on tooth development and wear for Rocky Mountain mule deer. The Journal of Wildlife Management 21: 134-153.

STAMP, J. T. 1962. Scrapie: A transmissible disease of sheep. The Veterinary Record 74: 357-362.
STEMSHORN, B. W. 1975. Un cas de tremblante naturelle chez un echevre. Canadian Veterinary Journal 16: 84-86.

Williams, E. S., AND S. Young. 1980. Chronic wasting disease of captive mule deer: A spongiform encephalopathy. Journal of Wildlife Diseases 16: 89-98.

, AND

1982. Spongiform encephalopathy of Rocky Mountain elk. Journal of Wildlife Diseases 18: 465-471.

, AND

1992. Spongiform encephalopathies in Cervidae. Revue Scientifique et Technique Office International des Epizooties 11: 551-567.

- AND - 1993. Neuropathology of chronic wasting disease in mule deer (Odocoileus hemionus) and elk (Cervus elaphus nelsoni). Veterinary Pathology 30: 36-45.

Received for publication 16 April 1996. 